\title{
Climate Change, Macroeconomic Sensitivity And The Response of Remittances To The North African Countries: A Panel VAR Analysis
}

Hajer HABIB ( $\nabla$ hajerhabib.k@gmail.com )

University of Tunis El Manar: Universite de Tunis El Manar https://orcid.org/0000-0002-7375-6920

\section{Research Article}

Keywords: Remittances, GDP, Climate Change, Adaptation, North Africa, PVAR

Posted Date: September 8th, 2021

DOl: https://doi.org/10.21203/rs.3.rs-719164/v1

License: (c) (1) This work is licensed under a Creative Commons Attribution 4.0 International License.

Read Full License 


\author{
Countries: A Panel VAR Analysis
}

\begin{abstract}
The paper analyses the role of remittances in alleviating the Gross domestic product (GDP) oscillations induced by a climate shock that is detected by irregular precipitation and annual temperature in the North African region between 1980 and 2016. By controlling endogeneity problems, we use the Panel Vector Autoregressive model (PVAR). Our results show on the one hand that the decline in precipitation and the increase in temperature have adverse consequences on the GDP per capita. On the other hand, remittances are a pathway of action towards macroeconomic stability of the most vulnerable countries to climate change. They are characterized by countercyclical patterns which increase the capacity of adaptation to meteorological changes in the recipient countries and also resistance to hazards. Therefore, the future policies must be more rigorously focused on adaptation policies and investing in green technologies that mitigate the long term negative consequences of climate transformations.
\end{abstract}

Keywords Remittances, GDP, Climate Change, Adaptation, North Africa, PVAR

\title{
1 Introduction
}

The theme of the environment and climate change forms an essential point of international debates on the development of countries regardless of their degree of development. In light of the evolution of climate change in recent years, the United Nations (UN 2015) has designated 17 Sustainable Development Goals (SDGs). These goals are part of a broader sustainable development for 2030 aimed at combating poverty, inequality and dealing more intensely with the issue of climate change. Remittances are also one of the main concerns of this programme. With regard to Goal 10, which refers about limiting inequalities within and between countries, one of the targets (Target 7) is to reduce, by 2030, the costs of migrant remittances to less than 3\% (UNDP 2015). This goal emphasises the importance of remittances, particularly in developing regions. In fact, they have grown at an astonishing speed since the early 2000s and now represent a significant source of external finance in developing countries (Ebeke and Le-Goff, 2010). According to a World Bank report (2020), the volume of remittances to developing countries reached a record \$529 billion in 2019, before a drop of 7\% following the Covid-19 health crisis. In addition, the first target of Goal 13 of the SDGs, entirely devoted to climate change, is entitled "Take urgent action to combat climate change and its impacts" (UNDP 2015). This target aims to support and develop the capacity of countries to adapt to the consequences of climate change.

According to the Intergovernmental Panel on Climate Change (IPCC 2007), "Climate change refers to a change in the state of the climate that can be identified by changes in the mean and/or the variability of its properties, and that persists for an extended period, typically decades or longer". IPCC (2007) shows that vulnerability to climate change indicates how susceptible and unable a country is to adjust to the unfavourable repercussions of climate variability and its extremes. As such, developing countries, particularly those in Africa, are in the crosshairs. The African continent has a generally hot and dry climate where more acute global warming and precipitation shortages compared to a century ago have caused a deep drought (Hulme et al. 2005). This region has an economic structure based especially on agriculture, the yields of which are obviously dependent on the climate (Schilling et al. 2020). Climate change therefore damaging the livelihoods of populations on a greater scale. On this continent, as in other parts of the world, the response to climate risks may take the form of the displacement of one or a variety of household members. For this, there is an urgent utility to assess the strategic role of migration to cope with climate change and climate-related disasters.

For developing countries, migration is identified among the processes of adaptation to climate variability that requires vulnerable households to seek alternative sources of additional income (Mahrajan et al. 2020; Singh and Basu 2019; Geddes 2015; IPCC 2014; Adger et al. 2003). Nori et al. (2009) show that this approach is similar to the new economics of labour migration founded by Stark and Bloom (1985) which emphasize that household members act collectively to face risks. Indeed, remittances are among the risk management strategies of the recipient families. Findley (1994) shows that $63 \%$ of households rely on migrant remittances during the drought period in some African countries. Afriyie et al. (2018) see that migration is an effective solution to enable households to diversify their income and strengthen the resilience of those facing environmental change. These results reveal on the one hand the importance of international migration as a source of remittances to origin countries and on the other hand the importance of migration as a guarantee against climate risks.

The Mediterranean area is grappling with increased migratory mobility. While migrant state that the financial constraints are the most common motivations of migration (Zuccotti et al. 2018; Flahaux and De Haas 2016), studies also show that environmental changes are not less important (Tegegne and Penker 2016; Marchiori et al. 2012). The North African countries are particularly affected by climate change because of their spatial position, 
close to the deserts, making them extremely vulnerable to increasing temperature and decreasing precipitation and their economic dependence on agriculture. In this region, Cook et al. (2016) specify the power fluctuation in precipitation volume from year to year and associated drought periods and heat waves. Temperature and precipitation are two fundamental determinants for understanding the households' behaviour in the face of climate variability, particularly for countries like North African countries, where rain-fed agriculture is dominant. The expected increase in temperature will inevitably lead to higher evapotranspiration, an irregularity of precipitation, thus aggravating the agricultural situation in the region. Given its intrinsic climate characterized by significant variability, the consequences of climate change increase the precariousness of North African countries at both socio-economic and environmental levels.

Although a variety of research on economic growth and migrant remittances can be found in the literature, we suggest an innovative way to debate the issue in the context of climate change. Indeed, the term climate change in our study is devoted to medium or long term changes in precipitation and temperature. We use cross-border macroeconomic data to discuss the hypothesis that remittances are a countercyclically response to GDP instability due to climate change in North African countries.

The central objective of this article is to identify the responsibility of remittances to cope with and adjust to the negative effects of climate change on the volatility of GDP growth in North Africa countries. It is in this perspective that we approached the following questions, what is the role assumed by remittances in alleviating the oscillations of the GDP induced by the meteorological fluctuation? And, are these remittances a significant factor in the adaptability of countries vulnerable to climate change shocks?

The article will be structured into four sections. The first section will focus on presenting the theoretical and empirical literature on the impact of remittances on GDP volatility in the context of climate change. The second section will provide a description of the research methodology. The third section will analyse the empirical results. In the last section, we will draw the main conclusions and reflect on the political implications of the results.

The difficulties associated with weather shocks are undoubtedly one of the major issues of today. Nevertheless, rarely is the academic evidence that has been provided about the correlation between climate variability, macroeconomic sensitivity, and migration response as an adaptation strategy. Indeed, the originality of this study lies in the methodological approach used and the integration into the model of climate data model in order to quantify the response of remittances to climate variability. The application of an autoregressive vector model of panel data (PVAR) makes it possible to test the responsiveness of migrants' remittances to fluctuations in climate variables, and to assess their influence on the economic growth of North Africa countries.

\section{Climate Change, GDP Volatility, and Remittance Response: A Literature Review}

Much research attempts to examine the influence of climate change on the instability of economic growth in developing regions. Some studies have concluded that climate volatility has a relatively humble effect on GDP. Raddatz (2009) shows that the influence of external shocks on the variability of GDP can be justified by domestic determinants such as inflation, the overestimation of the exchange rate, poor quality of institutions... By following a sample of 109 countries from 1970 to 2003, Noy (2009) finds that structural determinants such as high level of education, better institutions, trade openness, which resist the risks of climate variability on GDP fluctuations. A study of 32 developed countries, Murlidharan and Shah (2001) find that natural shocks for all countries have an appreciable effect on economic growth in the short term, but in the long term this effect is alleviated. The same results are given by Noy and Nualsri (2007) in which the macroeconomic effects of long term climatic shocks are negative but less important compared to the short term effects. Based on the neoclassical growth hypothesis, Caselli and Malhotra (2004) analyse losses from natural disasters relative to growth rates from a panel of 172 countries for events between 1975 and 1996. The authors concluded the hypothesis that the labour losses and the capital stock have no effect on long term economic growth. In a study on the Tunisian economy, Wiebelet et al. (2014) confirm the hypothesis that climate change has a negative overall effect but remains weak.

Other research has concluded that climate variability has a considerable negative influences on the economic growth. Through the GMM method, Loaysa et al. (2009) concentrate on evaluating the influence of climate risks on a panel of developing regions. The authors show that long term disasters such as droughts have negative consequences and almost instantaneous impact on the economies of the most marginalized countries. For Latin American countries, Otero and Marti (1995) note that there are serious effects of short term ecological transformations when national income is reduced, and they consider that these changes as an impediment to development in the developing countries more sensitive to natural shocks. Using a panel of Sub-Saharan African countries, Schleypen et al. (2019) show that an increase of $1^{\circ} \mathrm{C}$ in the annual average temperature coincides with a negative response of $0.8 \%$ of GDP per capita and an increase of $2^{\circ} \mathrm{C}$ achieves a reduction of $7.4 \%$ of GDP per capita. For the MENA region, Péridy et al. (2012) report that any increase in temperature of $1{ }^{\circ} \mathrm{C}$ causes a drop in GDP of around $0.4 \%$ to $1.3 \%$ and GDP per capita of around $8 \%$ on average (15\% in Egypt), however, the effect of the drop in precipitation on GDP per capita remains insignificant overall. Schilling et al. (2020) show that changes in temperature and rainfall have negative consequences for the largely rain-fed agricultural sector in North Africa. In the case of Tunisia, Kronik and Clément (2013) prove that the effects of climate change on agriculture 
adversely affect the livelihoods of the most vulnerable households. In Egypt, Asseng et al. (2018) show that wheat yields are expected to fall due to climate change, yet the improvements achieved as a result of crop intensification and the expansion of irrigated areas. In addition, Skidmore and Toya (2002) identify a robust positive relationship between natural shocks and long term economic growth after conditioning with other determinants, justified by the Schumpeterian "creative destruction"1 mechanism.

The growing concern of the world about the meteorological variability and its repercussions pushes countries to make all necessary efforts to limit the negative effects of change, among these strategies we find a migration (Sobczak-Szelc and Fekih 2020; Geddes 2015; Wamsler and Brink 2014).

Related literature with adaptation strategies suggests that remittances are additional income that accentuates or remains stable after major shocks such as climate disasters, economic and political crises (Edelbloude et al. 2017; Combes et al. 2014; Coulibaly et al. 2012; Mohapatra et al. 2009; Azam and Gubert 2006). The same idea treated by the World Bank (2006) which suggests that migrant remittances flows increase as a result of macroeconomic, financial and natural crises, and act as a safety net for households that have migrants abroad. Following Elbadawi and Rocha (1992), Agarwal and Horowitz (2002), the majority of empirical studies highlight the altruistic motivation of migrants to send remittances to their origin countries. Given this premise, remittances play a smoothing role when the economy of the origin country is hit by a crisis. In the context of climate change, migrants' remittances can be a tool to diminish the negative household effects of climate instability. Based on a panel of developing regions, Bettin et al. (2014) discover that remittances rise in reaction to unfavourable exogenous risks, such as climate transition. By following an autoregressive integrated moving average model (ARIMA) to predict GDP over a medium-term after a natural catastrophe, Hochrainer (2009) emphasizes the function of remittances as a major means of diminishing the negative macroeconomic impacts caused by a climate shock. For a panel of countries, Sayan (2006) estimates that there is a countercyclical relationship between remittances and GDP growth for the sample as a whole. Also, Ebeke (2010) reports that remittances create a form of insurance against all types of risks. The author finds a strong countercyclical relationship of remittances to real GDP. Based on a panel of 113 countries, Chami et al. (2003) show that the cyclical dynamics of remittances are countercyclical and promote economic growth. Yang and Choi (2007) conclude that increased hurricane exposure in poorer countries is associated with a more significant response to remittance flows. As well as Yang (2005) concludes that about 60\% of the exogenous decreases in income of the Philippine agricultural households due to rainfall risks are offset by migratory income. Ratha (2006) notes that remittances tend to increase with the eventuality of a natural disaster in Bangladesh, Dominican Republic, Haiti and Honduras. In the Caribbean countries, Mishra (2005) estimates that a $1 \%$ reduction in real GDP is associated with a favourable response from migrant remittances of $3 \%$. In El Salvador, the earthquake in 2001 strengthens both the probability of a household member migrating to the United States by $24.3 \%$ and remittances in order to smooth household consumption and to compensate for the loss of assets (Halliday, 2006). For South Asian countries, Mahrajan et al. (2020) explain that migration is used as one of the main adaptation strategies to climate restrictions. In India, Singh and Basu (2019) and Gupta (2005) report a positive influence of droughts on remittances. Gupta et al. (2009) test the cyclical nature of remittances on the real GDP of sub-Saharan African countries by determining such a countercyclical relationship over the period from 1996 to 2006. Using Ethiopian household survey data, Alem et al. (2016) conclude a non-negligible positive relationship between migration and meteorological instability as measured by precipitation irregularity. The authors show that rural Ethiopian households resort to sending remittances from existing migrants abroad when faced with precipitation variability. In the case of North African countries, Bilgili and Marchand (2016) show that remittances increase in response to climate shocks. In this regard, these flows of foreign funds function as coping mechanisms. Sobczak-Szelc and Fekih (2020) analyse the strategies of Tunisian households to deal with and a possibility to adjust for the negative influence of climate changes on agricultural areas. The authors explain that Tunisian households seek to rise their resilience to climate change via the additional resources such as remittances.

Despite a wide range of theoretical and empirical research which attempts to demonstrate the hypothesis of the robustness of remittances to face adverse exogenous risks to developing economies, but the results are frequently uncertain and do not offer sufficient evidence importance with regard to the impact of remittances on alleviating fluctuations in GDP. Consequently, we propose an empirical modelling, which is based on a VAR approach on a panel of North African countries, in order to test the dynamic link of the influence of climate variability on per capita GDP and the dynamic reaction of formal remittances.

${ }^{1}$ The expression is associated with the economist Schumpeter J. (1883-1950). The idea is inspired by the thought of the philosopher Friedrich Nietzsche (1844-1900). The process of Schumpeterian "creative destruction" is defined as the movement where simultaneously occurs the disappearance of sectors of economic activity and the creation of new sectors of economic activity. 
To shed light on this issue, we propose an annual data set encompassing five North African countries: Algeria, Egypt, Morocco, Mauritania and Tunisia, except Libya due to lack of available data, and the chronological panel dimension which covers a long period from 1980 to 2016. Our aim is to test the hypothesis that migrant remittances can be a strategy to limit climate variability on the economy in the recipient region. We use a methodology that emphasizes the variation in precipitation and temperature increase and their impact on GDP growth, evaluating the dynamic response of remittances.

Due to their geographical position, the North Africa countries are among the regions of the world more sensitive to climate variability and in particular to irregular precipitation and increase in temperature (Péridy et al. 2012). The region's climate is classified as hot and semi-arid. The annual average temperature of the sample is around $22.5^{\circ} \mathrm{C}$ over the period from 1980 to 2016 , but the maximum average value for Mauritania is $29^{\circ} \mathrm{C}$ in 2016 . In summer it can reach $39^{\circ} \mathrm{C}$ and in winter it can drop to $9^{\circ} \mathrm{C}$. The annual average rainfall does not exceed $152.5 \mathrm{~mm}$ over the same period, with a minimum value of $50.1 \mathrm{~mm}$ in Egypt and a maximum value of $521.52 \mathrm{~mm}$ in Morocco followed by Tunisia of $400.45 \mathrm{~mm}$ (table 1). Inter-country climate change may lead to waves of drought making some land unsuitable for agriculture. These environmental requirements can also be aggravated by a relatively weak adaptive capacity of populations. Due to the predominance of rain-fed agriculture in North African countries, the economic influence of the agricultural sector is significant and characterized by increased dependence on rainfall patterns. The difficult climate threatens the livelihoods of households. Among the factors likely to affect the link between climate risks and GDP fluctuations, we take into account the impact of remittances on macroeconomic stability and their interactions with climate variables (precipitation and temperature). Remittances represent one of the fundamental and most stable sources of foreign exchange to North Africa countries. Between 2000 and 2020, official remittances increased by around 600\% in Algeria, Egypt, Morocco, Mauritania and Tunisia. These countries received an average of $\$ 6.84$ million in remittances in 2020 (World Bank 2020).

Following Sims (1980), most researchers have chosen VAR models as the most efficient methodology for estimating of variabilities in terms of exogenous risks. In this framework, we apply the same model to panel data following the programme of Love and Zicchino $(2006)^{2}$, for to evaluate the fragility of GDP due to climate change and the potential role of remittances as an aspect of stability in selected countries. Indeed, a panel VAR model presents advantages over other methods because it allows to benefit from both the advantages of the standard VAR model and panel data techniques. The PVAR model remedied the endogeneity problems by allowing liaison between the endogenous variables of the model. Panel techniques circumvent the problem of small series sizes by combining spatial and temporal dimensions, which allows for more robust results. The PVAR model makes it possible to study the dynamic repercussions of economic variables via the impulse response functions (IRF).

The econometric regression is estimated for the specification of a four-variable VAR model in the first order as follows:

$$
Y_{i t}=\Gamma(L) Y_{i t}+u_{i t}+v_{i}+\varepsilon_{i t}
$$

$Y_{i t}$ is a vector of stationary variables that consists of the four variables: GDPpc (real GDP per capita in adjusted purchasing power parity (PPP)), REMITpc (remittances per capita) and two climate variables TM (temperature in $\mathrm{C}^{\circ}$ ) and $P R$ (precipitation in $\mathrm{mm}$ ). These variables are expressed in logarithm (log) as follows:

$$
\left(\begin{array}{c}
\ln G D P p c \\
\ln R E M I T p c \\
\ln T M \\
\ln P R
\end{array}\right)=\Gamma(L)\left(\begin{array}{c}
\ln G D P p c \\
\ln R E M I T p c \\
\ln T M \\
\ln P R
\end{array}\right)+u_{i}+v_{t}+\varepsilon_{i t}
$$

$\Gamma(\mathrm{L})$ is a matrix polynomial of the shift operator (L), in the following form :

$$
\Gamma(L)=\Gamma_{1} L_{1}+\Gamma_{2} L_{2}+\cdots+\Gamma_{p} L_{p}
$$

And, $u_{i}$ is a vector of country-specific effects to account for the unobserved heterogeneity of countries, $v_{t}$ is a vector of time-specific effects and $\varepsilon_{i t}$ is a vector of idiosyncratic errors.

We apply the real GDP per capita (PPP adjusted) data from the Penn World table ${ }^{3}$ (Feenstra et al., 2015). Real GDP per capita is measured by the log of real GDP divided by the total population of each country (real GDP on the production side to chained PPPs (in US\$ millions of 2017) and the population (in millions)). This variable is more effective than overall GDP in assessing a country's development. Workers' remittances and compensation

\footnotetext{
${ }^{2}$ Using the package of a Stata program provided by Inessa Love (2001) to estimate a panel VAR. This specification is redeveloped by Love and Zicchino (2006) which uses the Stata code (PVAR).
}

${ }^{3}$ Feenstra et al. (2015) "The Next Generation of the Penn World Table", American Economic Review, 105 (10), 3150-3182. This table contains data from the Penn World Table (PWT), version 10.0 (2021)), available at www.ggdc.net/pwt. 
of employees received per capita ${ }^{4}$ obtained from World Bank services' migration and remittance data (2020) based on IMF balance of payments statistics and data publications from central banks, national statistical agencies and World Bank country offices. Climate data are obtained from the University of East Anglia (UEA) Climatic Research Unit (CRU) database for climate variables temperature and precipitation. In fact, these both variables exhibit significant spatial and inter-annual variability. This database presents monthly gross data variations from January 1901 to December 2016 at the global level. Therefore, we try to calculate the annual average of monthly precipitation and temperature data for each country in our sample.

Table 1 Descriptive statistics of the variables

\begin{tabular}{clccc}
\hline Variables & \multicolumn{1}{c}{ Description } & Mean & Min & Max \\
\hline GDPpc & $\begin{array}{l}\text { Real GDP on the production side at chained } \\
\text { PPPs (in millions of US dollars of 2017) divided } \\
\text { by the total population of each country. }\end{array}$ & 5972.12 & 1345.052 & 13462.52 \\
\hline REMITpc & $\begin{array}{l}\text { Per capita remittances are obtained by dividing } \\
\text { the total amount of remittances by the total } \\
\text { population of each country. }\end{array}$ & 74.7409 & 0.44456 & 227.7906 \\
\hline$T M$ & The average annual temperature level $\left({ }^{\circ} \mathrm{C}\right)$. & 22.5231 & 17.0574 & 29.20067 \\
\hline$P R$ & The average annual level of precipitation $(\mathrm{mm})$. & 152.4819 & 18.8263 & 521.5178 \\
\hline
\end{tabular}

Period: (1980-2016), $\mathrm{T}=37$ and Country: $\mathrm{N}=5$

( Panel: $\mathrm{T} * \mathrm{~N}=185$ )

Source: Author's calculation

The specification of a PVAR model indicates that there is a problem with the existence of fixed effects linked to the regressors that offers biased coefficients, identified by $v_{t}$ in the model (equation 2). According to Sevestre (2002), the fixed effects estimator is not consistent because the individual constant is related to one of the lagged endogenous variables. To remedy this problem, we adopt the process of difference of endogenous variables of future observations, also named the Helmert transformation for eliminating disturbances (Love and Zicchino 2006). In this differentiation, all the variables integrated in the model are transformed into deviations from the future average.

Let: $\bar{y}_{i t}^{m}=\sum_{s=t+1}^{T_{i}} y_{i t}^{m} /\left(T_{i}-t\right)$, denotes the averages constructed from the future values of $y_{i t}^{m}$ a variable in the vector $Y_{i t}=\left(y_{i t}^{1}, y_{i t}^{2}, \ldots, y_{i t}^{m}\right)^{\prime}$, with $T_{i}$ is the last period of accessible data for a given panel of countries. Let: $\bar{\varepsilon}_{i t}^{m}$ the same as $\varepsilon_{i t}=\left(\varepsilon_{i t}^{1}, \varepsilon_{i t}^{2}, \ldots, \varepsilon_{i t}^{m}\right)^{\prime}$.

The transformations are given by:

$$
\tilde{y}_{i t}^{m}=\delta_{i t}\left(y_{i t}^{m}-\bar{y}_{i t}\right)
$$

$\tilde{\varepsilon}_{i t}^{m}=\delta_{i t}\left(\varepsilon_{i t}^{m}-\bar{\varepsilon}_{i t}\right)$

With : $\delta_{i t}=\sqrt{\frac{T_{i}-t}{T_{i}-t+1}}$, the final transformed model is given by:

$$
\tilde{Y}_{i t}=\Gamma(L) \tilde{Y}_{i t}+\tilde{\varepsilon}_{i t}
$$

With : $\tilde{Y}_{i t}=\left(\tilde{y}_{i t}^{1}, \tilde{y}_{i t}^{2}, \ldots, \tilde{y}_{i t}^{m}\right)^{\prime}$ et $\tilde{\varepsilon}_{i t}=\left(\tilde{\varepsilon}_{i t}^{1}, \tilde{\varepsilon}_{i t}^{2}, \ldots, \tilde{\varepsilon}_{i t}^{m}\right)^{\prime}$.

This transformation removes only the average of all available future observations for each country-year. Since this procedure keeps the orthogonality between the transformed variables and the regressors, we use lagged values of the regressors as instruments and we estimate the coefficients of the transformed model by the GMM method (Arellano and Bover 1995). After evaluation of the parameters of the model, we focus on the interaction among the variables through Impulse Response Functions (IRF) ${ }^{5}$ which determine the reaction of one variable to the shocks of another variable of the model, while preserving all other variables unchanged. As well as the Forecast

\footnotetext{
${ }^{4}$ Remittances from workers and compensation of employees include current transfers made by migrant workers, plus wages and salaries earned by non-resident workers. Per capita remittances are obtained by dividing the total amount of remittances by the total population of each country. All figures are in current US dollars. For the latest data on migration and remittances, please visit https://www.knomad.org/data/remittances, World Bank (2020).

${ }^{5}$ To analyse impulse response functions (IRF), we need an estimate of the confidence interval using the MonteCarlo simulation (Garita 2011). This step produces a new matrix of parameters $(\Gamma)$ and calculates the IRFs through a variance-covariance matrix of the residuals of the new estimated parameters.
} 
Error Variance Decomposition (FEVD) ${ }^{6}$, which are measured using the Cholesky decomposition suggested by Sims (1980). The basic hypothesis of this decomposition is that the variables emerging in the first position affect the following variables at the like period and with a lag, while the variables emerging in the second position affect just the previous variables with a lag (Love and Zicchino 2006).

In this sense, the variables that appear first in the VAR order are considered more exogenous and those that appear later are largely endogenous. Then, we order the variables according to the results of the Granger causality test in the context of a Wald test. In each model, the Wald test has a probability lower than a 5\% significance level of remittances per capita and real GDP per capita, which are treated as endogenous. On the other hand, the climate variables are not subject to any reverse causality with GDP and remittances (table 3), so we suppose that temperature and precipitation are exogenous. According to these results, the Cholesky order of the variables is as follows: PR, TM, REMITpc and GDPpc (equation 2).

\section{7}

258

259

260

261

262

263

264

265

\section{Empirical results and economic interpretations}

Using a PVAR modelling framework allows us to increase the power of the analysis given the limitations of the data. Like the standard VAR model, to overcome the problem of a fallacious regression, the panel VAR estimation requires the determination of the optimal lag through the evaluation of the stationarity of the time series before the specification of the model. To do this, we used the panel unit root tests Im, Pesaran and Shin (2003) (IPS) and the Fisher test using the augmented Dickey-Fuller test (ADF) to examine the stationarity of the variables. Hurlin and Mignon (2005) show that the IPS (2003) test is preferred over others because it converges when T is low $(\mathrm{T}<30)$. The results are presented in table 2, both for the level and first difference variables.

Table 2 Unit root tests and cointegration analysis

\begin{tabular}{|c|c|c|c|c|c|}
\hline \multirow[t]{2}{*}{ Variables } & \multicolumn{2}{|c|}{$\begin{array}{l}\text { Im, Pesaran and Shin } \\
\text { (IPS 2003) }\end{array}$} & \multicolumn{2}{|c|}{$\begin{array}{c}\text { Fisher chi-squared } \\
\text { (Augmented Dickey-Fuller (ADF)) }\end{array}$} & \multirow[t]{2}{*}{ I(.) } \\
\hline & Stat de test & P-value & Stat de test & P-value & \\
\hline $\operatorname{lnGDPpc}$ & 1.9230 & 0.9728 & 2.0322 & 0.9961 & $\mathrm{I}(1)$ \\
\hline$\Delta \operatorname{lnGDPpc}$ & -10.6008 & 0.0000 & 304.1134 & 0.0000 & \\
\hline $\operatorname{lnREMITpc}$ & 0.2357 & 0.5932 & 11.3551 & 0.3305 & $\mathrm{I}(1)$ \\
\hline$\Delta \operatorname{lnREMITpc}$ & -9.7041 & 0.0000 & 279.1356 & 0.0000 & \\
\hline $\operatorname{lnTM}$ & -3.9046 & 0.0000 & 43.0872 & 0.0000 & $\mathrm{I}(0)$ \\
\hline$\Delta \operatorname{lnTM}$ & - & - & - & - & \\
\hline $\operatorname{lnPR}$ & -7.4373 & 0.0000 & 161.2246 & 0.0000 & $\mathrm{I}(0)$ \\
\hline$\Delta \ln P R$ & - & - & - & - & \\
\hline
\end{tabular}

Notes: a IPS (2003) and ADF (1979) unit root tests.

${ }^{\mathrm{b}} \mathrm{Ho}$ : The series has a unit root.

Ha: The series does not have a unit root. The series is stationary.

The results show clearly that the variables GDPpc and REMITpc are non-stationary in levels. Indeed, the null hypothesis of non-stationary series are verified by the statistics of unit root tests. However, they become stationary at a significance level of 5\% when we test the unit roots of the first difference panel because the null hypothesis of non-stationary is rejected. This confirms that these variables are integrated of order one (I (1)). Howe ver, the climate variables are integrated of order zero (I (0)). Following these results, equation (2) is rewritten as follows:

$$
\left(\begin{array}{c}
\Delta \ln P R \\
\Delta \ln T M \\
\Delta \ln R E M I T p c \\
\Delta \ln G D P p c
\end{array}\right)=\Gamma(L)\left(\begin{array}{c}
\Delta \ln P R \\
\Delta \ln T M \\
\Delta \ln R E M I T p c \\
\Delta \ln G D P p c
\end{array}\right)+u_{i}+v_{t}+\varepsilon_{i t}
$$

According to the statistics, the IPS and ADF tests both reject the null hypothesis (H0) of non-cointegration that the series has a unit root and retain the alternative hypothesis (Ha) that it is stationary. We conclude that the variables are stationary only in the first difference, which gives an idea of the existence of an error correction for the individual panel effects and also for the total panel.

Based on the literature, the optimal number of lags in our PVAR (p) model is based on the minimization of selection criteria such as Akaike (AIC) and Schwarz (SC) as in the standard VAR (Abrigo and Love 2016; Miller et al. 2010). Indeed, the correct choice of lags is fundamental for a PVAR model because if the relatively concise

\footnotetext{
${ }^{6}$ The variance decomposition (FEVD) presents the ratio of the variance of each of these shocks (innovations) to
} the total variance of the forecast error. 
lags do not approve to capture the dynamics of the model, which results from a bias of omitted variable. However, too much lags results in a loss of freedom level, due to over-parameterization.

The choice of the number of lags $(\mathrm{p}=0 \ldots . \mathrm{k})$ has an important role in the estimation of the model. By adopting the maximum lag as possible, two lags are chosen $(\mathrm{k}=2)$. The estimated PVAR (2) model is as follows:

$$
\left(\begin{array}{c}
\Delta \ln P R \\
\Delta \operatorname{lnTM} \\
\Delta \ln R E M I T p c \\
\Delta \ln G D P p c
\end{array}\right)=\Gamma_{1}\left(\begin{array}{c}
\Delta \ln P R(L 1) \\
\Delta \ln T M(L 1) \\
\Delta \ln R E M I T p c(L 1) \\
\Delta \ln G D P p c(L 1)
\end{array}\right)+\Gamma_{2}\left(\begin{array}{c}
\Delta \ln P R(L 2) \\
\Delta \ln T M(L 2) \\
\Delta \ln R E M I T p c(L 2) \\
\Delta \ln \operatorname{LDPp}(L 2)
\end{array}\right)+\left(\begin{array}{c}
\varepsilon_{1} \\
\varepsilon_{2} \\
\varepsilon_{3} \\
\varepsilon_{4}
\end{array}\right)
$$

Once the stationarity order is defined, the next step is to analyse the model cointegration test to determine if there is a long term relationship between the set of integrated variables. Granger (1988) notes that when a time series is cointegrated, it requires following a long term equilibrium trajectory between variables with short-term adjustment to long term equilibrium. Indeed, the causality tests examine the reciprocal links among the model variables.

Table 3 Granger Causality/Block Exogeneity Wald Tests for PVAR model

\begin{tabular}{|c|c|c|c|c|c|c|c|}
\hline \multicolumn{4}{|c|}{ Dependent variable $(\Delta \operatorname{lnGDPpc})$} & \multicolumn{4}{|c|}{ Dependent variable $(\Delta \ln R E M I T p c)$} \\
\hline Excluded & Chi-sq & df & P-Value & Excluded & Chi-sq & $\mathrm{df}$ & P-Value \\
\hline$\Delta \operatorname{lnREMITpc}$ & 2.538 & 2 & 0.281 & $\Delta \operatorname{lnGDPpc}$ & 1.167 & 2 & 0.558 \\
\hline$\Delta \operatorname{lnTM}$ & 0.750 & 2 & 0.687 & $\Delta \ln \mathrm{TM}$ & 0.372 & 2 & 0.830 \\
\hline$\Delta \ln P R$ & 0.919 & 2 & 0.632 & $\Delta \ln P R$ & 1.641 & 2 & 0.440 \\
\hline All & 7.136 & 6 & 0.308 & All & 3.642 & 6 & 0.725 \\
\hline \multicolumn{4}{|c|}{ Dependent variable $(\Delta \operatorname{lnTM})$} & \multicolumn{4}{|c|}{ Dependent variable $(\Delta \ln P R)$} \\
\hline Excluded & Chi-sq & df & P-Value & Excluded & Chi-sq & df & P-Value \\
\hline$\Delta \operatorname{lnGDPpc}$ & 29.585 & 2 & 0.000 & $\Delta \operatorname{lnGDPpc}$ & 10.124 & 2 & 0.006 \\
\hline$\Delta \operatorname{lnREMITpc}$ & 3.639 & 2 & 0.162 & $\Delta \operatorname{lnREMITpc}$ & 0.861 & 2 & 0.650 \\
\hline$\Delta \ln \mathrm{PR}$ & 3.923 & 2 & 0.141 & $\Delta \operatorname{lnTM}$ & 6.105 & 2 & 0.047 \\
\hline All & 30.831 & 6 & 0.000 & All & 23.109 & 6 & 0.001 \\
\hline
\end{tabular}

Notes: Causality test in the sense of Granger (1988).

Ho: The excluded variable does not cause the equation variable in the sense of Granger.

Ha: The excluded variable causes the equation variable in the sense of Granger.

In view of all the above, the GMM method developed by Arellano and Bonds (1995) is the method used to estimate the model. The results of a PVAR (2) model with four variables are given in table 4. The Impulse Response Functions (IRF) are presented in figure 2. And, the results of the Forecast Error Variance Decomposition (FEVD) function are presented in table 5.

Table 4 Estimation results of the PVAR (2) model with 4 variables, GMM

\begin{tabular}{|c|c|c|c|c|c|}
\hline \multicolumn{3}{|c|}{ EQ1- dep-variable: $\Delta \ln P R$} & \multicolumn{3}{|c|}{ EQ2- dep-variable: $\Delta \ln T M$} \\
\hline \multicolumn{3}{|r|}{ t-GMM } & \multicolumn{3}{|c|}{$\mathrm{t}-\mathrm{GMM}$} \\
\hline \multirow[t]{2}{*}{$\Delta \ln P R$} & \multirow{2}{*}{$\begin{array}{l}\text { L1 } \\
\text { L2 }\end{array}$} & $-.57442(-8.86) * * *$ & \multirow[t]{2}{*}{$\Delta \ln P R$} & \multirow{2}{*}{$\begin{array}{l}\text { L1 } \\
\text { L2 }\end{array}$} & $-.00996(-1.60)^{*}$ \\
\hline & & $-.15953(-2.57) * * *$ & & & $-.00852(-1.82)^{*}$ \\
\hline \multirow[t]{2}{*}{$\Delta \ln \mathrm{TM}$} & \multirow{2}{*}{$\begin{array}{l}\text { L1 } \\
\text { L2 }\end{array}$} & $-.32264(-0.31)$ & \multirow[t]{2}{*}{$\Delta \operatorname{lnTM}$} & \multirow{2}{*}{$\begin{array}{l}\text { L1 } \\
\text { L2 }\end{array}$} & $-.53486(-6.68) * * *$ \\
\hline & & $-1.0923(-2.40)^{* *}$ & & & $-.08752(-2.84) * * *$ \\
\hline \multirow[t]{2}{*}{$\Delta \operatorname{lnREMITpc}$} & \multirow{2}{*}{$\begin{array}{l}\mathrm{L} 1 \\
\mathrm{~L} 2\end{array}$} & $.03121(0.89)$ & \multirow[t]{2}{*}{$\triangle \operatorname{lnREMITpc}$} & \multirow{2}{*}{$\begin{array}{l}\mathrm{L} 1 \\
\mathrm{~L} 2\end{array}$} & $-.00342(-1.18)$ \\
\hline & & $.01937(0.56)$ & & & $-.00320(-1.66)^{*}$ \\
\hline \multirow[t]{2}{*}{$\Delta \operatorname{lnGDPpc}$} & \multirow{2}{*}{$\begin{array}{l}\text { L1 } \\
\text { L2 }\end{array}$} & $.45226(1.01)$ & \multirow[t]{2}{*}{$\Delta \operatorname{lnGDPpc}$} & \multirow{2}{*}{$\begin{array}{l}\text { L1 } \\
\text { L2 }\end{array}$} & $-.03075(-0.82)$ \\
\hline & & $-.17326(-3.13) * * *$ & & & $.01789(5.32)^{* * *}$ \\
\hline \multicolumn{3}{|c|}{ EQ3- dep-variable: $\Delta \operatorname{lnREMITpc}$} & \multicolumn{3}{|c|}{ EQ4- dep-variable: $\Delta \operatorname{lnGDPpc}$} \\
\hline \multicolumn{3}{|r|}{ t-GMM } & \multicolumn{3}{|c|}{ t-GMM } \\
\hline
\end{tabular}




\begin{tabular}{|c|c|c|c|c|c|}
\hline \multirow[t]{2}{*}{$\Delta \ln P R$} & \multirow{2}{*}{$\begin{array}{l}\text { L1 } \\
\text { L2 }\end{array}$} & $.06453 \quad(0.70)$ & \multirow[t]{2}{*}{$\Delta \operatorname{lnPR}$} & \multirow{2}{*}{$\begin{array}{l}\text { L1 } \\
\text { L2 }\end{array}$} & $.00916(0.50)$ \\
\hline & & $-.03439(-0.31)$ & & & $.01417(0.90)$ \\
\hline \multirow[t]{2}{*}{$\Delta \operatorname{lnTM}$} & \multirow{2}{*}{$\begin{array}{l}\text { L1 } \\
\text { L2 }\end{array}$} & $-.17518(-0.13)$ & \multirow[t]{2}{*}{$\Delta \operatorname{lnTM}$} & \multirow{2}{*}{$\begin{array}{l}\text { L1 } \\
\text { L2 }\end{array}$} & $.14573(0.71)$ \\
\hline & & $-.46691(-0.61)$ & & & $-.02458(-0.23)$ \\
\hline \multirow[t]{2}{*}{$\Delta \operatorname{lnREMITpc}$} & \multirow{2}{*}{$\begin{array}{l}\text { L1 } \\
\text { L2 }\end{array}$} & $-.15803(-1.15)$ & \multirow[t]{2}{*}{$\Delta \operatorname{lnREMITpc}$} & \multirow{2}{*}{$\begin{array}{l}\text { L1 } \\
\text { L2 }\end{array}$} & $-.00068(-0.09)$ \\
\hline & & $.07686(0.71)$ & & & $.01252(1.86)^{*}$ \\
\hline \multirow[t]{2}{*}{$\Delta \operatorname{lnGDPpc}$} & \multirow{2}{*}{$\begin{array}{l}\text { L1 } \\
\text { L2 }\end{array}$} & $-.64798(-1.07)$ & \multirow[t]{2}{*}{$\Delta \operatorname{lnGDPpc}$} & \multirow{2}{*}{$\begin{array}{l}\text { L1 } \\
\text { L2 }\end{array}$} & $.29234(2.53)^{* * *}$ \\
\hline & & $.02786(0.29)$ & & & $.02742(1.67)^{*}$ \\
\hline
\end{tabular}

Notes: ${ }^{a}$ Robust standard errors in parentheses, $* * *=p<0.01 ; * *=p<0.05, *=p<0.1$.

$\mathrm{b}$ The 4-variable PVAR (2) model is estimated by the GMM method.

${ }^{c}$ Strongly balanced estimation sample over the period 1980 to 2016.

Before estimating the IRF and predicting the FEVD, we start of all check the stability properties of the estimated PVAR model. The stability of PVAR (2) requires that the module of the eigenvalues of the dynamic matrix is in the unit circle. Figure 1 confirms that all the eigenvalues are inside the unit circle. The PVAR (2) model satisfies the stability condition.

Fig 1 Stability condition of the eigenvalues

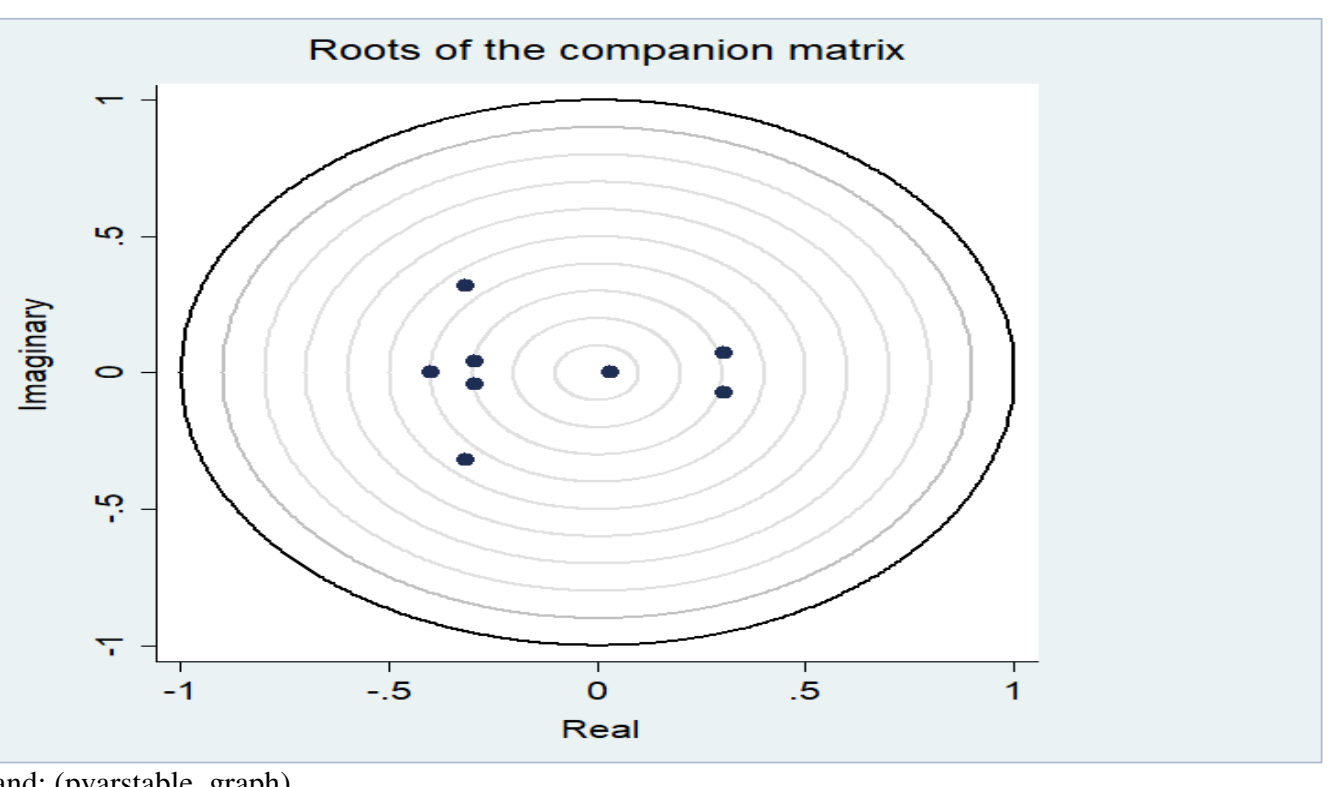

Note: ${ }^{a}$ stata command: (pvarstable, graph)

b Source: author's estimate.

The PVAR (2) approach examines the dynamic relationships between the variables of the model after the appearance of an exogenous (unexpected) climate risk associated with the series. The IRF are obtained on confidence intervals generated by Monte-Carlo simulation (200 repetitions) over a 10-year horizon which begins from the moment of the shock occurs. In this regard, they can be interpreted as the response of a variable to the impact on another variable in the model, keeping all the rest constant. Lutkepohl (1993) shows that this response can be considered as a percentage change of the log in the standard deviation. The IRF analysis is complemented by an analysis of the FEVD for an objective to obtain a global view of the dynamics of the shock affecting a system. It allows to calculate, in percentage, the contribution of the instantaneous or delayed shock suffered by one variable on the response of another.

Figure 2 traces the impulse response functions which are estimated based on the PVAR model of two lags, the coloured area representing the confidence interval at a significance level of $95 \%$. We are interested in the effects of changes over 10 periods which represent a sufficient time for the variables to regain their long-term stability. The IRF results examine the dynamic consequences of climate variables on GDP and also the influence of remittances to mitigate climate fluctuations.

Fig 2 Results of the impulse response functions in the PVAR (2) model 


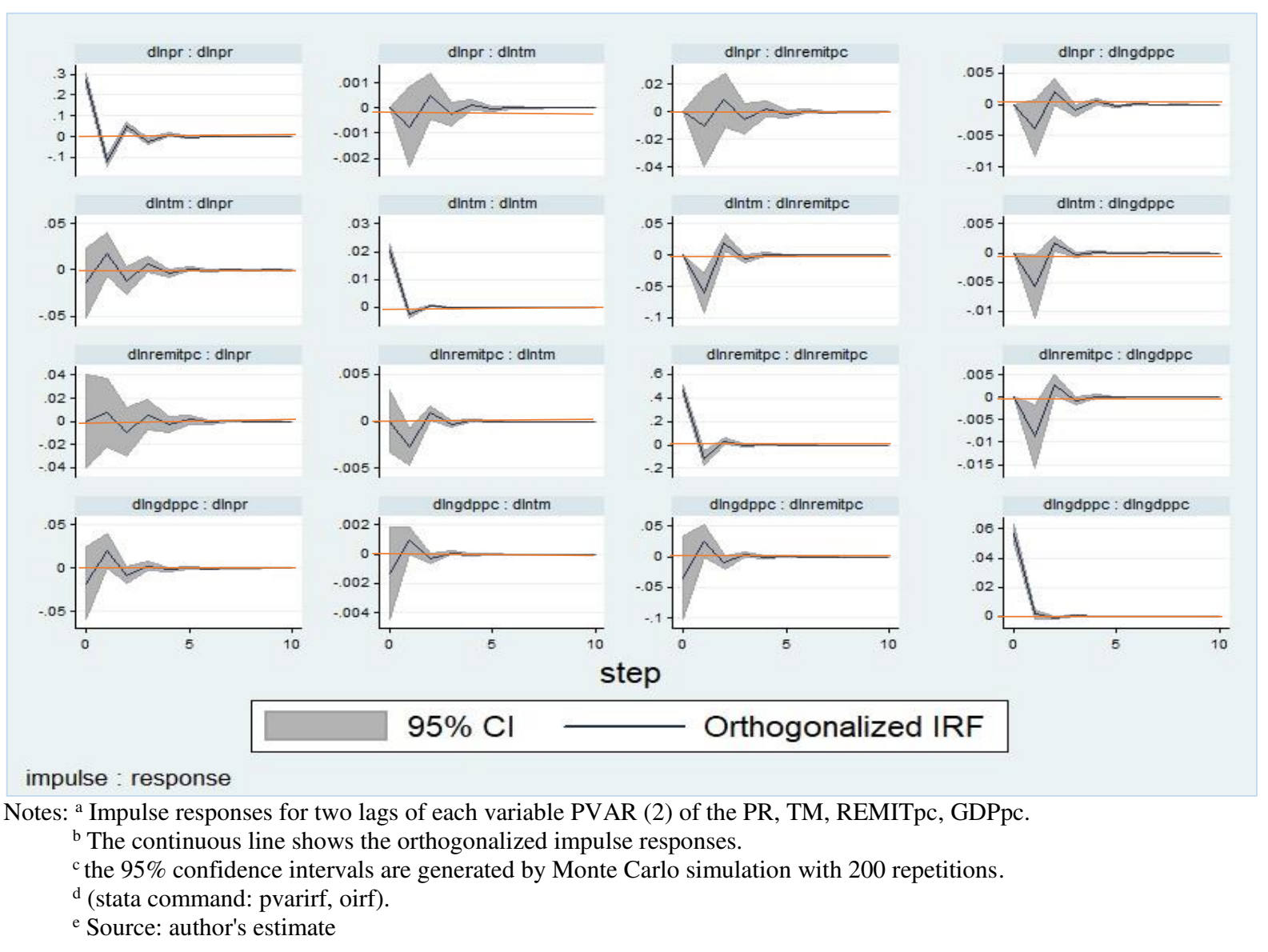

Our results indicate that a negative shock corresponds to an unexpected decrease in annual precipitation in North African countries in the first year of the shock occurrence (a negative variation from $30 \%$ to $-10 \%$ respectively between $\mathrm{t}=0$ and $\mathrm{t}=1$ ) results in a statistically significant decrease in GDP per capita for the second period after the start of the shock with a negative variation of $-2 \%$ between $t=1$ and $t=2$. These results are in line with the study by Generoso (2012) which shows, in the case of West African countries, that these countries characterized by a dry climate register, during a random shock of precipitation, a negative response $-0.74 \%$ of the GDP as well as the immediate response of the countries characterized by a humid climate is $-1.5 \%$ of the GDP. Indeed, an unfavourable random shock on the cyclical component of precipitation in the region stimulates migrants' remittances. This foreign flow record a positive variation of $1.7 \%$, then an adverse response results in a decrease in the amounts received progressively as the shock is diluted until reaching negative values for the year after the occurrence of shock (a variation of $-2.1 \%$ between $\mathrm{t}=1$ and $\mathrm{t}=2$ ). The remittance inflows register a disturbance before stabilizing five years after the shock occurs. However, precipitation accounts for only $1.7 \%$ of the variation in remittances. This may be due to a substantial proportion of migrant remittances sent over the unofficial channels. Several studies show that the real value of remittances is certainly much higher for developing countries if we consider unofficial remittances, which represent between $50 \%$ and $250 \%$ of those recorded in the balance of payments (Coiffard 2009).

Also, when the temperature registers an unexpected positive shock in North Africa (a positive variation from $1 \%$ to $+2 \%$ respectively between $\mathrm{t}=0$ and $\mathrm{t}=1$ ) in response to a decrease in precipitation, we see an immediate disturbance of the GDP per capita, which registers a negative variation of $-0.13 \%$ between $\mathrm{t}=1$ and $\mathrm{t}=2$ and $\mathrm{a}$ stability in the third year $(\mathrm{t}=3)$. These results correspond to the results obtained by Wiebelet et al. (2014), which confirms a combined impact of climate change (lower precipitation and higher temperatures) leading to a reduction in Tunisian GDP by $0.2 \%$ and $0.4 \%$. Hochrainer (2009) and Raddatz (2007) also show that climate shocks have a negative impact on GDP and GDP per capita by $-0.5 \%$ and $-2 \%$ respectively after one year. In the medium and long term, Raddatz (2009) shows that the GDP per capita decreases following a climate shock of $-0.6 \%$. As a result, the change in temperature records a decrease in remittances from migrants of $-0.7 \%$ in the first year of the shock $(\mathrm{t}=1)$ and a weak contribution of remittances of $0.5 \%$ to the reduction of the GDP with a one-year lag $(\mathrm{t}=2)$. The third year of the shocks occurrence saw a stabilization of the amounts of remittances sent to North African countries in order to overcome household budget constraints in the event of a shock.

The reaction of remittances becomes more significant after the fluctuation of GDP caused by precipitation and temperature shocks. Despite the decrease in the amounts transferred in the first year of the shock, it registers a significant positive effect on economic growth when the initial shock has passed one year (between $t=1$ and $t=2$ ) 
from $-0.8 \%$ to $0.25 \%$ and a relative stabilization of remittances from the third year after the shock. This can be interpreted by the altruistic migrant motivation which accentuate remittances to origin countries during periods of crisis. Our results validate the hypothesis that remittances have countercyclical response to the occurrence climate risks (Singh and Basu 2019; Ebeke 2010; Yang and Choi 2007; Sayan 2006). The results of the impulse functions of the PVAR (2) model indicate that remittances increase immediately when climate shocks appear in the North Africa countries. We show, in case of low precipitation, the remittances increase at the same time, and in case of the increase in temperature, the remittances increase one year after the initiate of the shock. For the entire panel, the response of remittances to climate shocks increases between the first and second year after the shock occurs. The IRF results also indicate that the effect of climate change ends up stabilizing in the fifth year when the response of macroeconomic variables becomes insignificant.

Although impulse responses provide information about the effect of changes from one variable on another, they do not show the contribution of shocks on one variable to explain the fluctuations in another variable. To assess the importance of changes in one variable in explaining changes in other variables, we perform a variance decomposition.

379 Table 5 Results of variance decomposition functions in the PVAR (2) model

\begin{tabular}{|c|c|c|c|c|c|}
\hline \multirow{2}{*}{$\begin{array}{l}\text { Response } \\
\text { variables }\end{array}$} & \multicolumn{5}{|c|}{ Impulse variables } \\
\hline & Step & $\Delta \ln P R$ & $\Delta \operatorname{lnTM}$ & $\Delta \operatorname{lnREMITpc}$ & $\Delta \operatorname{lnGDPpc}$ \\
\hline$\Delta \ln P R$ & 2 & .996091 & .0118467 & .0047389 & .0015424 \\
\hline$\Delta \ln \mathrm{TM}$ & 2 & .003199 & .9784335 & .0011986 & .0037859 \\
\hline$\Delta \operatorname{lnREMITpc}$ & 2 & .0003651 & .004227 & .9894254 & .0267458 \\
\hline$\Delta \operatorname{lnGDPpc}$ & 2 & .0073937 & .0054929 & .004637 & .9679258 \\
\hline$\Delta \operatorname{lnPR}$ & 5 & .9861861 & .0136779 & .0065839 & .0046407 \\
\hline$\Delta \ln \mathrm{TM}$ & 5 & .0023986 & .9723151 & .0015187 & .0042736 \\
\hline$\Delta \operatorname{lnREMITpc}$ & 5 & .0014973 & .0054111 & .9871138 & .0345221 \\
\hline$\Delta \operatorname{lnGDPpc}$ & 5 & .009918 & .0085958 & .0047836 & .9565636 \\
\hline$\Delta \ln P R$ & 10 & .9860709 & .0139883 & .006589 & .0046408 \\
\hline$\Delta \operatorname{lnTM}$ & 10 & .0025118 & .9719874 & .0015201 & .0042789 \\
\hline$\Delta \operatorname{lnREMITpc}$ & 10 & .0014993 & .0054156 & .9871022 & .0345311 \\
\hline$\Delta \operatorname{lnGDPpc}$ & 10 & .0099181 & .0086088 & .0047888 & .9565491 \\
\hline
\end{tabular}

Notes: ${ }^{\text {a }}$ The forecast error variance decomposition functions (FEVD) are calculated with 2, 5 and 10 periods.

${ }^{\mathrm{b}}$ The estimated regressions use two lags of each variable.

${ }^{c}$ The order of the Cholesky decomposition is: $\Delta \ln P R, \Delta \operatorname{lnTM}, \Delta \operatorname{lnREMITpc}, \Delta \operatorname{lnGDPpc}$

d (stata command: pvarfevd, mc (200)).

${ }^{\text {e }}$ Source: author's calculation

The results derived from the FEVD presented in table 5 are used to assess the extent to which the variability of the dependent variable is lagged by its own variance. In addition, it shows which of the independent variables is the "strongest" to explain the variability of the dependent variables over time. The results of the FEVD study for a panel of North African countries indicate that the variance of the forecast error of GDP per capita is explained at $95.65 \%$ of its own innovations and that the shocks related to precipitation and temperature are respectively $0.99 \%$ and $0.86 \%$ of the variance of GDP over the 5 and 10 -year horizon. For low-income countries, like evidence has been obtained by Raddatz (2009) which shows that external shocks to GDP represent just a small percentage of the whole variance of real GDP as well as the extensive part of the variance is due to endogenous factors. Therefore, the climate variables can be considered as exclusively exogenous variables (Granger causality test, table 3) because we consider North African countries to be exhibited to physical factors such as precipitation variability and temperature increase as described by official country statistics. In our model, the climate variables represent $1.85 \%$ of the whole variance of GDP. Given the impact of remittances $(0.47 \%)$, all the variables contained in the model, justify just $2.32 \%$ of the variance of GDP per capita after 10 years. Thus, $97.68 \%$ of the variance of GDP are defined by other factors not contained in our model. The variance of remittances is mentioned by $4.19 \%$ by whole the variables contained in the model and by a share only about $0.69 \%$ of the climate factors after a period of 10 years. Therefore, $95.8 \%$ of the variance of remittances can be justified by other variables omitted from the model. Our study deals purely the shortage of precipitation and temperature and does not consider the effects of internal shocks on remittances. This could justify most of the remittances variance that the model does not explain. 

considerable influence on GDP per capita. However, the reaction of remittances to GDP shocks emerge lower direct and further complex to examine. The IRF results show that the response of remittances to a standard deviation innovation on GDP per capita remains insignificant over time, even if the standard error bands (obtained by Monte-Carlo simulation with 200 repetitions) are closed at the zero line in periods 3 and 4 years. This indicates that remittances are accentuated in the case of climate risk which has a significant and negative influence on GDP growth if all other variables are held at zero 3 years after the appearance of the shock. So, we show that remittances have appreciable indirect repercussions on GDP, acting as a source of income "stabilization". Our results support the hypothesis that remittances depend on GDP fluctuations in the origin countries. The results of the forecast error variance decomposition of the PVAR (2) model confirm our conclusions and show that the variance of remittances per capita contributes a share of $3.45 \%$ in the GDP per capita fluctuations after 10 years. These findings corroborate those of Cruz-Zuniga (2011) which shows that the contribution of remittances can only explain a small percentage of the GDP variance of $4.09 \%$ in the long term.

In summary, the results of the variance decomposition (FEVD) in the PVAR model with two lags values reveal that meteorological variables proposed by the model are explanatory determinants in the GDP instability in the North African region. The reactions of GDP per capita to precipitation irregularity and temperature increase are considerable in the model. Climate variables, both contribute to small volatility, but remain statistically significant for the variance of GDP per capita $(1.85 \%)$ and the variance of remittances $(0.7 \%)$. Fluctuations in GDP explain a positive response from remittances to North African countries with a variance of $3.45 \%$ as the shock dilutes after 10 lags. This suggests that foreign remittances are a significant flow of funds to origin countries in times of climate change, contribute to resilience to climate variability, and then have indirect effects on GDP fluctuations.

\section{Conclusions and Policy Implications}

Climate change is a major source of concern in Africa as in the world, and migration is often understood as one of the many adjustment and livelihood diversification strategies used to react to climate and environmental vulnerability. Climatic conditions will shape the development trajectories today, as they are closely linked to the economic, social and political situation of countries. As a result, Africa is considered a hotspot of vulnerability (UNEP 2011).

Focusing on five North African countries, this study aims to evaluate the responsiveness of migrants' remittances to mitigate climate shocks over extensive GDP fluctuations, using a VAR estimation methodology of panel data with two lags (PVAR (2)) between 1980 to 2016. The estimates of the impulse response functions and the decomposition of the variance show that the occurrence of an adverse rainfall shock result in a significant adverse response to GDP per capita in the short term. Our results also show that an unexpected positive temperature shock in response to precipitation variability negatively impacts GDP in the North African region. Remittances from altruistic migrants are countercyclical in reply to exogenous risks of precipitation and temperature between the first and second year after the shock appearance. Although climate change is not the main component of GDP fluctuations since it accounts for only $3.45 \%$, remittances are sensitive to climate shocks and they certainly have a significant impact that deserves even more attention given the contribution of these external flows to smoothing out macroeconomic oscillations. However, the countercyclical relationship of remittances to shocks to GDP can create an increased intensity of the dependence of recipient households on these incomes. This dependence has negative consequences on the macroeconomic performance of the beneficiary countries, in particular the increase in unemployment and the economic shortage of the most vulnerable households in the event of lockdown measures in response to a global crisis such as the Covid-19 health crisis (Habib 2020).

These results suggest important policy implications. This study shows that remittances are an important source of external income. These external flows can become a blessing for recipient countries, if policy makers give a concern to formal sending channels. As the literature shows, remittances play a considerable role in the development of low-income regions, international policies should help find easier ways, cheaper and less restrictive means of canalize these inflows to the most vulnerable regions. In a context of climate change, in order to help the households most vulnerable to shortages caused by climate change, it is important to strengthen governments' efforts regarding household resilience and to direct these flows towards profitable projects. Thus, these projects reduce economic dependence on rain-fed agriculture and strengthen the capacity for adaptation. Also an important aspect is to create methods of subsidies to make remittances accessible to the poorest households as these policies contribute to widen the gap between rich and poor households. On the other hand, during a return migration, the human capital that migrants can acquire during their migration is very valuable to the origin countries. They can transfer knowledge that will help countries cope with climate change, including water management, sustainable land management and other environmental practices.

Statements \& Declarations:

$460 \quad$ Funding Not applicable 
Data availability Data used for the study are available here

Real GDP per capita (PPP adjusted) data from the Penn World table: This table contains data from the Penn World Table (PWT), version 10.0 (2021)), available at www.ggdc.net/pwt

Workers' remittances and compensation of employees received per capita obtained from World Bank services' migration and remittance data (2020) at this link. https://www.knomad.org/data/remittances

Climate data are obtained from the University of East Anglia (UEA) Climatic Research Unit (CRU) database for climate variables temperature and precipitation. https://lr1.uea.ac.uk/cru/data

Materials availability Not applicable

Code availability We use the package of a Stata program provided by Love and Zicchino (2006) to estimate a panel VAR https://github.com/gaulinmp/accounting-predictability/blob/master/STATA/pvar.ado

\section{Declarations (ethics):}

Conflict of Interest / Competing interests The author declares no competing interests

Ethics approval Not applicable

Consent to participate Not applicable

Consent for publication Not applicable

\section{References}

Abrigo M, Love I (2016) Estimation of Panel Vector Autoregression in Stata: A Package of Programs. The Stata Journal, 16(3), 1-27 https://doi.org/10.1177/1536867X1601600314

Adger N, Huq S, Brown K., Conway D, Hulme M (2003) Adaptation to climate change in the developing world. Progress in Development Studies, 3 (3): 179-195 https://doi.org/10.1191/1464993403ps060oa

Agarwal R, Horowitz A (2002) Are international remittances altruism or insurance: Evidence from Guyana using multiple-migrant households. World Development, 2033-2044 https://doi.org/10.1016/S0305750X(02)00118-3

Afriyie K, Ganle J, Santos E (2018) The floods came and we lost everything': Weather extremes and households" asset vulnerability and adaptation in rural Ghana. Climate and Development, 10(3), 259-274. https://doi.org/10.1080/17565529

Alem Y, Maurel M, Millock K (2016) Migration as an Adaptation Strategy to Weather Variability: An Instrumental Variables Probit Analysis. Working Papers in Economics 665, University of Gothenburg, Department of Economics.

Arellano J, Bover O (1995) Another Look at the Instrumental Variable Estimation of Error-Components Model. Journal of Econometrics, Vol. 68(1), pp. 29-51 https://doi.org/10.1016/0304-4076(94)01642-D

Asseng S, Kheir A, Kassie B, Hoogenboom G, Abdelaal A, Haman D, Ruane A (2018) Can Egypt become self$\begin{array}{lllll}\text { sufficient in wheat? Environmental Research Letters } 13 & 094012\end{array}$ https://iopscience.iop.org/article/10.1088/1748-9326/aada50/meta

Azam J P, Gubert F (2006) Migrants' Remittances and the household in Africa: A Review of Evidence. Journal of African Economies 15: 426-462. https://doi.org/10.1093/jae/ej1030

Bettin G, Presbitero A, Spatafora N (2014) Remittances and Vulnerability in Developing Countries. International Monetary Fund, Working Paper WP/14/13

Bilgili Ö, Marchand K (2016) Migration, development and climate change in Egypt, Morocco and Tunisia. Climate Change, Displacement, Environmental Change, Swiss Agency for Development and Cooperation https://environmentalmigration.iom.int/migration-development-and-climate-change-egypt-morocco-and$\underline{\text { tunisia }}$

Boubtane E, Coulibaly D, Rault C (2012) Immigration, Growth and Unemployment: Panel VAR Evidence from OECD Countries. IZA Discussion Paper No. 6966

Caselli F \& Malhotra P (2004) Natural Disasters and Growth: from Thought Experiment to Natural Experiment. International Monetary Fund. 
Chami R., Fullenkamp C, Jahjah S (2003) Are Immigrant Remittance Flows a Source of Capital for Development? International Monetary Fund, Working Paper 03/189 DOI: 10.12691/jbe-5-1-2

Coiffard M (2009) La régulation des transferts de fonds de migrants, vers un régime international ? Post-Print halshs-00390424, HAL.

Combes J, Ebeke C, Etoundi M, Yogo T (2014) Are foreign aid and remittance inflows a hedge against food price shocks in developing countries? World Development, 54 (1), 81-98.

Cook B, Anchukaitis K, Touchan R, Meko D., Cook E. (2016) Spatiotemporal drought variability in the Mediterranean over the last 900 years. J Geophys Res-Atmos 121:2060-2074. https://doi.org/10.1002/2015JD023929

Cruz-Zuniga M (2011) On the path to economic growth, do remittances help? Evidence from panel VARs. The Developing Economies 49, no. 2 (June 2011): 171-202, https://doi.org/10.1111/j.1746-1049.2011.00128.X

Ebeke C, Le Golf M (2010) Impact des envois de fonds des migrants sur les inégalités de revenu dans les pays en développement. Revue économique, Vol. 61(6), Paris, pp. 10511074.

Ebeke C (2010) Transferts des migrants, ouverture sur l'extérieur et dépenses publiques dans les pays en développement", Working Paper 201011, CERDI.

Edelbloude J, Fontansers C, Makhlouf, F. (2017) Do Remittances respond to Revolutions? The Evidence from Tunisia. Research in International Business and Finance 42 https://doi.org/10.1016/j.ribaf.2017.04.044

Elbadawi I, Rocha R (1992) Determinants of Expatriate Workers' Remittances in North Africa and Europe Policy Research Working Paper no.1038. Washington, D.C.: World Bank.

Feenstra R, Inklaar R, Timmer M (2015) The Next Generation of the Penn World Table. American Economic Review, 105 (10), 3150-3182, DOI: 10.1257/aer.20130954

Findley S (1994) Does Drought Increase Migration? A Study of Migration from Rural Mali during the 1983- 1985 Drought. International Migration Review 28(3), 539-553 https://doi.org/10.2307/2546820

Flahaux M, De Haas H (2016) African migration: trends, patterns, drivers. CMS 4, 1. https://doi.org/10.1186/s40878-015-0015-6

Geddes A (2015) Governing migration from a distance: Interactions between climate, migration, and security in the South Mediterranean. European Security, 24(3), 473-490. https://doi.org/10.1080/09662839.2015.1028191.

Generoso R (2012) Transferts de fonds et résilience des pays d'Afrique de l'Ouest face à la variabilité des précipitations : une perspective macroéconomique. Cahier du CEMOTEV n²012-03.

Granger C (1988) Causality, cointegration, and control. Journal of Economic Dynamics and Control, 1988 , vol. 12, issue 2-3, 551-559 https://doi.org/10.1016/0165-1889(88)90055-3

Gupta P (2005) Macroeconomic Determinants of Remittances: Evidence from India. IMF Working Papers 05/224, International Monetary Fund. https://www.imf.org/en/Publications/WP/Issues/2016/12/31/MacroeconomicDeterminants-of-Remittances-Evidence-from-India-18728

Gupta S, Pattillo C A, Wagh S (2009) Effect of remittances on poverty and financial development in Sub-Saharan Africa. World Development, 37(1): 104-115. https://doi.org/10.1016/j.worlddev.2008.05.007

Habib H (2020). The Economic and Social Impact of the Novel Coronavirus (Covid-19) on Migrant Remittances: An Overview of Tunisia and Morocco. GLO Discussion Paper, No. 715, Global Labor Organization (GLO), Essen, https://ideas.repec.org/p/zbw/glodps/715.html

Halliday T (2006) Migration, Risk, and Liquidity Constraints in El Salvador. Economic Development and Cultural Change, 54(4): 893-925 https://www.jstor.org/stable/10.1086/503584

Hochrainer S (2009) Assessing the Macroeconomic Impacts of Natural Disasters - Are there Any? World Bank Policy Research Working Paper 4968. Washington, DC, United http://hdl.handle.net/10986/4162

Hulme M, Doherty R, Ngara T, New M (2005) Global warming and Africa climate change. Dans A. Low, Climate change and Africa (pp. 29-40). Cambridge: Cambridge University Press. DOI:10.2277/0521836344

Hurlin C, Mignon V (2005) Une synthèse des tests de racine unitaire sur données de panel. Economie et prévision, n¹69-170, pp. 253-294. 
Im K, Pesaran M, Shin Y (2003) Testing for unit roots in heterogeneous panels. Journal of Econometrics 115: 5374 https://doi.org/10.1016/S0304-4076(03)00092-7

IPCC, Intergovernmental Panel on Climate Change (2014) Climate Change (2014) Impacts, Adaptation, and Vulnerability. The Working Group II contribution to the IPCC Fifth Assessment Report. Geneva: Intergovernmental Panel on Climate Change.

IPCC, Intergovernmental Panel on Climate Change (2007) Climate change 2007 climate change impacts, adaptation and vulnerability", Cambridge University Press, Geneva

Kronik J, Clément V (2013) Socioeconomic Effects of Climate Change in Central and Southern Tunisia. Chapter 4 in Verner, D (ed.). 2013. Tunisia in a Changing Climate. Assessment and Actions for Increased Resilience and Development. The World Bank, Washington, DC.

Loayza N, Olaberría J, Rigolini, Christiansen L (2009) Natural Disasters and Growth Going Beyond the Averages. World Bank Policy Research Working Paper 4980. Washington, DC, United States: The World Bank http://hdl.handle.net/10986/4172

Love I, Zicchino L (2006) Financial Development and Dynamic Investment Behavior: Evidence for a Panel VAR. The Quarterly Review of Economics and Finance, vol.46, pp.190-210 https://doi.org/10.1016/j.qref.2005.11.007

Lutkepohl H (1993) Introduction to Multiple Time Series Analysis. 2nd Ed. New York: Springer. https://www.springer.com/gp/book/9783540569404

Maharjan A, Safra R, Singh C, ..., Vincent K (2020) Migration and Household Adaptation in Climate-Sensitive Hotspots in South Asia. Current Climate Change Reports (2020) 6:1-16, https://doi.org/10.1007/s40641-020$\underline{00153-\mathrm{Z}}$

Marchiori L, Maystadt J, Schumacher I (2012) The impact of weather anomalies on migration in sub-Saharan Africa. Journal of Environmental Economics and Management 63, 355-374 https://doi.org/10.1016/j.jeem.2012.02.001

Miller G, Geddes C, Mardon D (2010) Effects of excluding sheep from an alpine dwarf-herb community. Plant Ecology \& Diversity 3(1):87-93 https://doi.org/10.1080/17550871003713726

Mishra P (2005) Macroeconomic Impact of Remittances in the Caribbean. International Monetary Fund, Washington, DC.

Mohapatra S, Joseph G, Ratha D (2009) Remittances and Natural Disasters: Expost Response and Contribution to Ex-ante Preparedness. World Bank Policy Research

Murlidharan T, Shah H (2001) Catastrophes and macro-economic risk factors: An empirical study. Conference on "Integrated Disaster Risk Management: Reducing SocioEconomic Vulnerability. Laxenburg, International Institute for Applied Systems Analysis.

Noy I, Nualsri A (2007) What do Exogenous Shocks tell us about Growth Theories? University of Hawaii Working Paper 07-28.

Nori M, El Mourid M, Giorgi P, Nefzaoui A (2009) Herding in a Shifting Mediterranean Changing agro-pastoral livelihoods in the Mashreq \& Maghreb region. EUI Working Paper. RSCAS 2009/52. European University Institute.

Noy I (2009) The Macroeconomic Consequences of Disasters. Journal of Development Economics 88(2): 221231 https://doi.org/10.1016/j.jdeveco.2008.02.005

Otero R, Marti, R. (1995) The impacts of natural disasters on developing economies: implications for the international development and disaster community. Disaster Prevention for Sustainable Development: Economic and Policy Issues. M. Munasinghe and C. Clarke. The International Bank for Reconstruction and Development/The World Bank: 11-40.

Péridy N, Ghoneim A, Brunetto, M. (2012) The Economic Costs of Climate Change in MENA countries: A MicroSpatial Quantitative Assessment and a Survey of Policies. Femise Research Programme 2010-2011, FEMISE Project $n^{\circ} 34-03$

Raddatz C (2009) The Wrath of God: Macroeconomic Costs of Natural Disasters. World Bank Policy Research Working Paper, World Bank, Washington, DC. 
Raddatz C (2007) Are external shocks responsible for the instability of output in low income countries? Journal of Development Economics, Vol. 84(1) :155-187 https://doi.org/10.1016/j.jdeveco.2006.11.001

Ratha D (2006) Remittances trend. (No. 40088). Washington, DC http://hdl.handle.net/10986/11036

Sayan S (2006) Business Cycles and Workers Remittances: How Do Migrant Workers Respond to Cyclical Movements of GDP at Home? Working Papers 06/52, International Monetary Fund.

Sevestre P (2002) Économétrie des données de panel. Dunod, Paris.

Schilling J, Hertig E, Tramblay Y, Scheffran J (2020) Climate change vulnerability, water resources and social implications in North Africa. Regional Environmental Change, volume 20, num15 https://doi.org/10.1007/s10113-020-01597-7

Schleypen J, Saeed F, Dayamba S, Coulibaly D, D'haen S (2019) Impacts des changements climatiques sur l'économie (Produit Intérieur Brut et valeurs ajoutées sectorielles) et sur la productivité agricole au Burkina Faso. Projet d'Appui Scientifique aux processus de Plans Nationaux d'Adaptation. Sous la tutelle du Ministère de l'Environnement, de l'Economie Verte et du Changement Climatique du Burkina Faso, https://doi.org/10.13140/RG.2.2.20128.00003

Sims C (1980) Macroeconomics and reality. Econometrica, Vol. 48(1), pp. 1-48 https://www.jstor.org/stable/1912017

Singh C, Basu R (2019) Moving in and out of vulnerability: interrogating migration as an adaptation strategy along a rural urban continuum in India.The Geographical Journal, https://doi.org/10.1111/geoj.12328

Skidmore M, Toya H (2002) Do Natural Disasters Promote Long-run Growth? Economic Inquiry 40(4): 664-687 https://doi.org/10.1093/ei/40.4.664

Sobczak-Szelc K, Fekih N (2020) Migration as one of several adaptation strategies for environmental limitations in Tunisia: evidence from El Faouar. Comparative Migration Studies 8(1) https://doi.org/10.1186/s40878-0190163-1

Stark O, Bloom E (1985) The New Economics of Labour Migration. American Economic Review 75(2), 173-17 https://www.jstor.org/stable/1805591

Tegegne A, Penker M (2016) Determinants of rural out-migration in Ethiopia: Who stays and who goes? Demographic Research, vol. 35, issue 34, 1011-1044 https://doi.org/10.4054/DemRes.2016.35.34

UNDP, United Nations Development Program (2015) Consulté le Janvier 2021, sur https://www.un.org/sustainabledevelopment/fr/objectifs-de-developpement-durable/

UNEP, United Nations Environment Program (2011) Consulté sur le site www.unep.org/annualreport, ISBN : 978-92-807-3245-0, DCP/1493/NA

Wamsler C,Brink E (2014) Moving beyond short-term coping and adaptation. Environment \& Urbanization, International Institute for Environment and Development (IIED), Vol 26(1): 86-111, https://doi.org/10.1177/0956247813516061

Wiebelt M, Al-Riffai P, Breisinger C, Robertson R (2014) Who bears the costs of climate change? Evidence from Tunisia. Kiel Working Paper No. 1952, Kiel Institute for the World Economy, Kiellinie 66, 24105 Kiel, Germany

World Bank (2020) Migration and Development Brief 32: COVID-19 Crisis Through a Migration Lens. Washington DC: World Bank Group and KNOMAD, https://www.knomad.org/publication/migration-anddevelopment-brief-32-COVID-19-crisis-through-migration-lens

World Bank (2006) Global Economic Prospects 2006: Economic Implications of Remittances and Migration. World Bank, Washington, DC. https://openknowledge.worldbank.org/handle/10986/2140

Yang D (2005) Coping with Disaster: The Impact of Hurricanes on International Financial Flows, 1970-2001. Ford School of Public Policy Working Paper Series 2005-003, University of Michigan.

Yang D, Choi H (2007) Are remittances insurance? Evidence from rainfall shocks in the Philippines. The World Bank Economic Review, 21 (2): 219-248 https://www.jstor.org/stable/40282243

Zuccotti C, Geddes A, Bacchi A, Nori M, Stojanov R (2018) Rural Migration in Tunisia: Drivers and Patterns of Rural Youth Migration and its Impact on Food Security and Rural Livelihoods in Tunisia. Food and Agriculture Organization of the United Nations, 70 p. http://www.fao.org/documents/card/en/c/I9193EN/ 